\title{
Range extensions and conservation of some threatened or little known Brazilian grassland birds
}

\author{
LEONARDO ESTEVES LOPES, GUSTAVO BERNARDINO MALACCO, \\ EDUARDO FRANÇA ALTEFF, MARCELO FERREIRA DE VASCONCELOS, \\ DIEGO HOFFMANN and LUÍS FÁBIO SILVEIRA
}

\begin{abstract}
Summary
Populations of grassland birds are declining in Brazil due to profound alterations to grassland habitats. In this paper, we present recent records and range extensions for 12 threatened or little known Brazilian grassland species: Ocellated Crake Micropygia schomburgkii, Sickle-winged Nightjar Eleothreptus anomalus, Campo Miner Geositta poeciloptera, Rufous-sided Pygmytyrant Euscarthmus rufomarginatus, Sharp-tailed Grass-tyrant Culicivora caudacuta, Cocktailed Tyrant Alectrurus tricolor, Cinereous Warbling-finch Poospiza cinerea, Black-masked Finch Coryphaspiza melanotis, Tawny-bellied Seedeater Sporophila hypoxantha, Marsh Seedeater S. palustris, Chestnut Seedeater S. cinnamomea and Black-bellied Seedeater S. melanogaster. We also comment on the biogeography and conservation of these species.
\end{abstract}

\section{Resumo}

As populações de aves campestres brasileiras estão sofrendo tremendos impactos decorrentes das alterações sofridas pelos campos naturais. Neste estudo são apresentados registros e extensões na distribuição geográfica de 12 espécies de aves campestres brasileiras pouco conhecidas ou ameaçadas de extinção: Micropygia schomburgkii maxalalagá, Eleothreptus anomalus curiangodo-banhado, Geositta poeciloptera andarilho, Euscarthmus rufomarginatus maria-corruíra, Culicivora caudacuta papa-moscas-do-campo, Alectrurus tricolor galito, Poospiza cinerea capacetinho-do-oco-do-pau, Coryphaspiza melanotis tico-tico-de-máscara-negra, Sporophila hypoxantha caboclinho-de-barriga-vermelha, S. palustris caboclinho-de-papo-branco, S. cinnamomea caboclinho-de-chapéu-cinzento e S. melanogaster caboclinho-de-barriga-preta. Também são apresentados comentários sobre a conservação e a biogeografia dessas espécies.

\section{Introduction}

Although populations of many grassland birds have declined sharply throughout the Western Hemisphere during the past decades (Vickery et al. 1999), these species have received little attention compared to tropical forest birds (Willis and Oniki 1992, Stotz et al. 1996). Modernisation and mechanisation of agricultural practices in central Brazil during the last two decades resulted in profound changes in grassland habitats, which threatened several habitat-restricted birds with extinction (Parker and Willis 1997, Cavalcanti 1999). According to Wege and Long (1995), 12\% of the Neotropical bird species then threatened with extinction live in grasslands and savannas. Of the Neotropical species using grasslands as their primary habitat, $34 \%$ have high conservation priorities and $80 \%$ of the endemic lowland grassland birds of South 
America are at risk (Stotz et al. 1996). In this paper we present new records and range extensions for 12 threatened or little known Brazilian grassland birds, and discuss the main threats to them.

\section{Study area and methods}

We conducted intensive bird surveys in the state of Minas Gerais, southeastern Brazil, during the last 10 years, which resulted in a large amount of unpublished data. Here we summarize records of Near Threatened/Threatened (Collar et al. 1992, Machado et al. 2005, BirdLife International 2008) or little known grassland birds (sensu Vickery et al. 1999) observed during this period. The majority of these records were documented by digital photography or tape recordings that have been, or will be deposited in the Arquivo Sonoro Professor Elias Coelho, Universidade Federal do Rio de Janeiro, Brazil. We also report on some specimens deposited in the Brazilian ornithological collections of the Universidade Federal de Minas Gerais, Belo Horizonte (DZUFMG), Museu de Zoologia da Universidade de São Paulo, São Paulo (MZUSP) and Museu de História Natural de Taubaté, Taubaté (MHNT).

The six most important areas (Figure 1 ) for grassland species surveyed are described below. Vegetation community descriptions of the Cerrado biome follow Ribeiro and Walter (1998), and are only briefly described here: cerrado típico (a woodland 3-6 m tall with closed scrub and

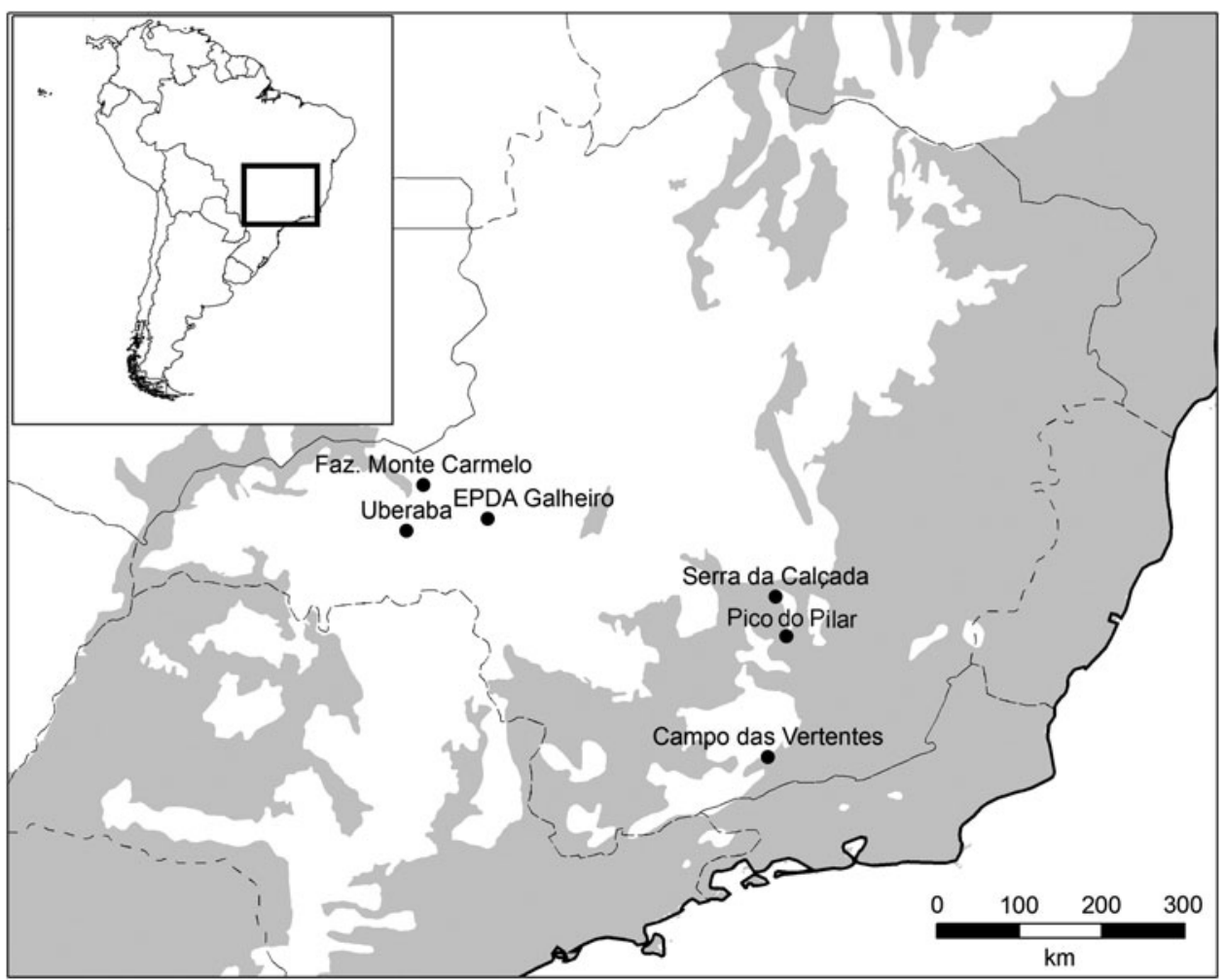

Figure 1. Grassland bird species rich areas surveyed in the state of Minas Gerais, southeastern Brazil. Gray shaded areas indicate forested regions, while white areas represent non-forested regions (according to Olson et al. 2001). 
scattered trees), cerrado ralo (more open scrub with a few trees), cerrado rupestre (similar to the cerrado ralo, but growing over rocky substrates), campo sujo (grassland with scattered shrubs), campo sujo com murundus (a grassland with small groves of trees on raised earth mounds associated with termite nests, also locally known as covoal), campo limpo (grasslands without woody plants), campos rupestres (rocky grassland with a very peculiar shrub and herbaceous vegetation growing over quartzite outcrops; Giulietti and Pirani 1988), canga (herbaceous and shrubby vegetation growing over iron ore outcrops; Vincent et al. 2002, Jacobi et al. 2007, Viana and Lombardi 2007) and vereda (stands of the palm Mauritia flexuosa growing in grass-covered swamps).

The main study areas and the localities sampled were:

Municipality of Uberaba: 1) Fazenda Cocal (19 $26^{\prime} \mathrm{S}$ and $48^{\circ} \mathrm{oo}{ }^{\prime} \mathrm{W} ; 915 \mathrm{~m}$ asl) and 2) Fazenda Água Emendada ( $19^{\circ} 17^{\prime} \mathrm{S}$ and $48^{\circ} \mathrm{Or}^{\prime} \mathrm{W}$; $950 \mathrm{~m}$ ).

Fazenda Monte Carmelo: a large Eucalyptus and Pinus plantation with grassland patches in the municipalities of Estrela do Sul, Monte Carmelo, Indianópolis, Araguari and Romaria. The headwaters of the following creeks were sampled: 1 ) Ribeirão Buriti Alto $\left(18^{\circ} 47^{\prime} \mathrm{S}\right.$ and $47^{\circ} 46^{\prime} \mathrm{W}$; $990 \mathrm{~m}$ ); 2) Ribeirão Piçarrão ( $18^{\circ} 48^{\prime} \mathrm{S}$ and $\left.47^{\circ} 53^{\prime} \mathrm{W} ; 975 \mathrm{~m}\right)$; 3) Ribeirão Furnas ( $18^{\circ}{ }^{\circ} \mathrm{O}^{\prime} \mathrm{S}$ and $47^{\circ} 50^{\prime} \mathrm{W} ; 18^{\circ} 50^{\prime} \mathrm{S}$ and $\left.47^{\circ} 52^{\prime} \mathrm{W} 970-980 \mathrm{~m}\right) ; 4$ ) Ribeirão Mandaguari ( $19^{\circ} \mathrm{O} 2^{\prime} \mathrm{S}$ and $47^{\circ} 42^{\prime} \mathrm{W}$; $990 \mathrm{~m})$ and 5) Vereda Barro Preto ( $18^{\circ} 59^{\prime} \mathrm{S}$ and $\left.47^{\circ} 4 \mathrm{o}^{\prime} \mathrm{W} ; 998 \mathrm{~m}\right)$.

Estação de Pesquisa e Desenvolvimento Ambiental Galheiro (EPDA Galheiro): a reserve in the municipality of Perdizes ( $19^{\circ} 12^{\prime} \mathrm{S}$ and $47^{\circ} \mathrm{O} 8^{\prime} \mathrm{W}$; 800-950).

Serra da Calçada: a hilly area $(1,100-1,500 \mathrm{~m})$ in the southern portion of the Espinhaço Range, in the municipalities of Nova Lima, Brumadinho and Ibirité: 1) Serra do Rola Moça State Park $\left(20^{\circ} \mathrm{O3}^{\prime} \mathrm{S}\right.$ and $\left.\left.44^{\circ} \mathrm{Oo}^{\prime} \mathrm{W}\right) ; 2\right)$ surroundings of Retiro das Pedras $\left(20^{\circ} \mathrm{O} 6^{\prime} \mathrm{S}\right.$ and $\left.43^{\circ} 59^{\prime} \mathrm{W}\right)$ and 3) Vale dos Cristais $\left(20^{\circ} \mathrm{oo}\right.$ 'S and $\left.43^{\circ} 54^{\prime} \mathrm{W}\right)$.

Pico do Pilar: another hilly area in the southern Espinhaço Range, municipality of Congonhas: 1) Casa de Pedra mine $\left(20^{\circ} 29^{\prime} \mathrm{S}\right.$ and $\left.\left.43^{\circ} 53^{\prime} \mathrm{W}\right) ; 2\right)$ Paiol de Explosivos $\left(20^{\circ} 27^{\prime} \mathrm{S}\right.$ and $\left.43^{\circ} 52^{\prime} \mathrm{W}\right)$ and 3) Batateiro $\left(20^{\circ} 28^{\prime} \mathrm{S}\right.$ and $\left.43^{\circ} 56^{\prime} \mathrm{W}\right)$.

Campo das Vertentes: a region of extensive high altitude (1,000-1,200 m) campos limpos in southern Minas Gerais, municipalities of Andrelândia, Bom Jardim de Minas and Lima Duarte, among others, sampled on June 2005: 1) farm belonging to Mr. G. C. Fonseca $\left(21^{\circ} 43^{\prime} \mathrm{S}\right.$ and $\left.44^{\circ} \mathrm{Oo}{ }^{\prime} \mathrm{W}\right)$; 2) farm belonging to Mr. P. S. Almeida $\left(21^{\circ} 43^{\prime} \mathrm{S}\right.$ and $\left.44^{\circ} \mathrm{O} 5^{\prime} \mathrm{W}\right)$; 3) Fazenda $4^{8}$ $\left(21^{\circ} 44^{\prime} \mathrm{S}\right.$ and $\left.44^{\circ} \mathrm{O} 3^{\prime} \mathrm{W}\right)$; 4) Souza $\left(21^{\circ} 48^{\prime} \mathrm{S}\right.$ and $\left.\left.44^{\circ} \mathrm{O} 5^{\prime} \mathrm{W}\right) ; 5\right)$ Fazenda Areão $\left(21^{\circ} 52^{\prime} \mathrm{S}\right.$ and $44^{\circ} \mathrm{O} 7^{\prime} \mathrm{W}$ ). A complete list of the birds observed in this region is available elsewhere (Pacheco et al. 2008).

\section{Species accounts}

The conservation status of each species follows Machado et al. (2005) and BirdLife International (2008) at the national and global levels, respectively. We present an updated range map for all species studied (see Supplementary Material). These maps were prepared based on unpublished field records, published records, and museum specimens (see acknowledgments).

Ocellated Crake Micropygia schomburgkii - Data Deficient (Machado et al. 2005).

This is a common species at the EPDA Galheiro, were it was recorded from January to November 2003 in cerrado ralo, cerrado rupestre, and cerrado típico. At Fazenda Monte Carmelo this species was recorded year round (2005-2008) inhabiting campo sujo com murundus and grasslands at Ribeirão Piçarrão, Ribeirão Mandaguari, Ribeirão Buriti Alto, Ribeirão Furnas and Vereda Barro Preto. Records at Fazenda Água Emendada are from February and November 2007 in cerrado típico. The first record of this species for Minas Gerais was presented by Pelzeln (1868-1870), who reported a specimen collected by Natterer at "Borda do Matto du Paranaiba", nowadays Borda da Mata (Paynter and Traylor 1991), near the border with the state of Goiás. Recent records for the state are from the Serra da Canastra National Park (Silveira 1998, Vasconcelos et al. 2006).

Sickle-winged Nightjar Eleothreptus anomalus - Near Threatened (Machado et al. 2005, BirdLife International 2008). 
A male was observed near Ijaci $\left(21^{\circ} 10^{\prime} \mathrm{S}\right.$ and $\left.44^{\circ} 55^{\prime} \mathrm{W} ; 840 \mathrm{~m}\right)$, southern Minas Gerais, in June 2004. A possible female of this species was observed on a dirt road at Campo das Vertentes (farm belonging to Mr. G. C. Fonseca) on 26 July 2005. This road crosses extensive grasslands, and the site record was located less than $30 \mathrm{~m}$ from a gallery forest. If confirmed, this record would represent a connection between the historical localities of Lagoa Santa and southern Brazil (Straube 1990, Bornschein et al. 1996, Kirwan et al. 1999, Cleere 2002). An adult male was collected on 30 April 1999 at Serra da Canastra (DZUFMG 2662).

Campo Miner Geositta poeciloptera - Vulnerable (Machado et al. 2005), Near Threatened (BirdLife International 2008).

One individual, observed and photographed on a dirt road at Campo das Vertentes (Fazenda 48) on 26 July 2005, represents the easternmost record of this species. On 27 October 2007 one individual was recorded at Fazenda Água Emendada in cerrado ralo, and about eight individuals were observed and photographed in the surrounding abandoned pastures on I November 2007 $\left(19^{\circ} 14^{\prime} \mathrm{S}\right.$ and $\left.48^{\circ} \mathrm{O} 5^{\prime} \mathrm{W} ; 900 \mathrm{~m}\right)$. This species was previously known from only seven localities in Minas Gerais. The first record for the state is one specimen collected by Natterer in June 1823 in São Domingos (Pelzeln 1868-1870). Three other historical records are from Uberaba, Paracatu and Lagoa Santa (Reinhardt 1870, Krabbe 2007). Recent occurrences in Minas Gerais are from Serra da Canastra, Tapira, and Patrocínio (Brandt 1998, Silveira 1998, Silva e Silva 2005, Vasconcelos et al. 2006).

Rufous-sided Pygmy-tyrant Euscarthmus rufomarginatus - Near Threatened (Machado et al. 2005, BirdLife International 2008).

On 1 and 2 October 2002 at least two individuals were tape-recorded in a transition zone between a seasonally flooded campo limpo and a campo sujo at Fazenda Cocal. This is the fifth record of this species for Minas Gerais (Supplementary materials), including the record for Parque das Mangabeiras, considered doubtful by D'Angelo Neto and Queiroz (2001). We found this species to be the most common flycatcher in campo sujo and cerrado ralo during a faunal inventory (January/February 2008) at Estação Ecológica Serra Geral do Tocantins, central Brazil $\left(10^{\circ} 39^{\prime} \mathrm{S}\right.$ and $\left.46^{\circ} 48^{\prime} \mathrm{W}\right)$. This is a large (c. 720 , 00o ha) conservation unit on the border of the states of Tocantins and Bahia. This species colonises recently burned areas and pairs were heard and seen every $200 \mathrm{~m}$ of transect on average. Four birds were collected (MZUSP 79673-76) with gonads inactive, despite the record of several young birds being fed by the parents. Stomach contents of these individuals revealed small fruits and insects in almost equal proportions. This species was also common in the adjacent Parque Estadual do Jalapão, Tocantins (Braz et al. 2003).

Sharp-tailed Grass-tyrant Culicivora caudacuta - Vulnerable (Machado et al. 2005, BirdLife International 2008).

Small groups of $2-3$ individuals were recorded in cerrado ralo and cerrado rupestre in April, May, July, August and November 2003 at the EPDA Galheiro. A small group (4-5 birds) was observed at Serra do Rola Moça State Park on May and August 2005. These birds were at $1,500 \mathrm{~m}$, representing a small altitudinal extension for the species, which was known to occur at a maximum of 1,400 m (Ridgely and Tudor 1994, Stotz et al. 1996). A small group (4-5 birds) was observed in Retiro das Pedras on August 2005. A small group was observed at Batateiro on December 2005. Two individuals were recorded at Fazenda Água Emendada in seasonally flooded campo limpo on 30 December 2005. This species was recorded year round (2005-2008) at Fazenda Monte Carmelo (Ribeirão Piçarrão, Ribeirão Mandaguari, Ribeirão Furnas, Ribeirão Buriti Alto and Vereda Barro Preto), where it inhabits seasonally flooded campo limpo and campo sujo com murundus. Censuses made in this area (2007/2008) revealed 88 individuals in 96 hours of observations. This species was recorded in several areas at Campo das Vertentes (farm belonging to Mr. G. C. Fonseca, Fazenda Areão, Souza, and farm belonging to Mr. P. S. Almeida), revealing that it is a locally common species. These are the easternmost records of $C$. caudacuta, extending the range $c .250 \mathrm{~km}$ to the east. The updated map expands the known range of this species to the north (600 km, Oren 1991) and south (450 km, Di Giacomo 2005) of its previously known range (see Supplementary materials). 
Two specimens (DZUFMG 4511, male, weighing 6.4 g and DZUFMG 4512, female, $5.7 \mathrm{~g}$ ) were found dead on 2 June 2005 in Retiro das Pedras. These birds were apparently hit when they attempted to cross the road. In the stomach of the male we found: 2 Araneae, I Orthoptera, 2 Hemiptera, 2 larvae of Lepidoptera, I adult Lepidoptera, I Diptera, and I Hymenoptera. In the stomach of the female (DZUFMG 4512, 5.7 g) we found: I Araneae, I Homoptera, I Diptera, and I Hymenoptera. The gizzards of two specimens deposited in the ornithological collection of the Reserva Ecológica do IBGE, Brasília, also contained only insects. This small sample size contradicts previous observations that this species "feeds on grass and weed seeds as well as more standard insect fare" (Traylor and Fitzpatrick 1982).

Cock-tailed Tyrant Alectrurus tricolor - Vulnerable (Machado et al. 2005, BirdLife International 2008).

On 2 October 2002, a pair was observed at Fazenda Cocal in a seasonally flooded campo limpo. One pair was observed and photographed in the Campo das Vertentes (farm belonging to Mr. G. C. Fonseca) in a seasonally flooded campo limpo. A small group of three females was observed nearby, but in a dry campo limpo. This species was recorded from August 2007 to April 2008 at Fazenda Monte Carmelo (Ribeirão Piçarrão, Ribeirão Mandaguari, Ribeirão Furnas and Ribeirão Buriti Alto), inhabiting seasonally flooded campo sujo, campo sujo com murundus, and veredas. On 27 August, a singing male was observed, but the long tail, characteristic of this species, was not fully grown. On 4 and 11 October, three males were observed exhibiting the typical flight display of this species (Sick 1997). On December 2007 we counted 26 individuals, on January and February seven individuals, and only five birds on April 2008.

Cinereous Warbling-finch Poospiza cinerea - Data Deficient (Machado et al. 2005), Vulnerable (BirdLife International 2008).

A summary of the records of this species for Minas Gerais was presented by Melo-Júnior (1998), with subsequent records obtained in central and southern Espinhaço Range (D'Angelo Neto and Queiroz 2001, Bencke et al. 2006, Vasconcelos 2007, Vasconcelos and D'Angelo Neto 2007). Unpublished records of this species are as follows: 1 ) One individual in a degraded campo sujo at Vale dos Cristais on 4 January 2002; 2) One individual in a degraded roadside at Pico do Pilar on 7 December 2002; 3) Two individuals on a degraded campo cerrado with several invasive plants at Bairro Belvedere, Belo Horizonte ( $19^{\circ} 58^{\prime} \mathrm{S}$ and $43^{\circ} 56^{\prime} \mathrm{W} ; 1,130 \mathrm{~m}$ ) on 4 June 2003 and two birds again in this same area on 11 May 2004; 4) Two individuals in degraded pastures and orchards in Fortaleza de Minas ( $20^{\circ} 53^{\prime} \mathrm{S}$ and $46^{\circ} 42^{\prime} \mathrm{W}$; $900 \mathrm{~m}$ ) on 3 October 2003, 25 November 2005, and 20 October 2006, when they were seen carrying nest material; 5) Two individuals in a poor second growth area at the EPDA Galheiro on November 2003; 6) One individual in a campo cerrado at Fazenda Virgulino, Santana do Riacho $\left(19^{\circ} \mathrm{O}^{\prime} \mathrm{S}\right.$ and $43^{\circ} 51^{\prime} \mathrm{W}$; $1,150 \mathrm{~m}$ ), on the western slope of Serra do Cipó, on 12 January 2005; 7) One individual in the canga of the Serra do Rola Moça State Park on 24 October 2005, 8) Three individuals on 20 November 2006 at Serra do Cabral, Joaquim Felício ( $17^{\circ} 42^{\prime} \mathrm{S}$ and $44^{\circ} 16^{\prime} \mathrm{W} ; 1,140 \mathrm{~m}$ ), in campo rupestre near marshy areas and degraded cerrado rupestre and 9) some pairs near the border of Serra da Canastra National Park, where it is resident and occupies pastures and other degraded areas. Although our observations indicate that this species is commonly found in degraded areas or habitats subject to regular human disturbance, our records are restricted to hilly areas in central-south Minas Gerais, and were always of single individuals or isolated pairs. We never found this species in degraded areas during our surveys in central Brazil, where it is rare. For example, this species seems to be extinct in Chapada dos Guimarães, Mato Grosso (Lopes et al. 2009).

There is evidence that this species is a recent colonizer of eastern Brazil, where it was observed inhabiting artificial pastures in areas previously covered by Atlantic Forest (Simon et al. 1999, Ribon 2002). Nevertheless, a specimen collected in the municipality of Viçosa in 1936, and deposited at the Museu Nacional, Rio de Janeiro (not numbered), indicates that this species was present in the area studied by Ribon (2002) much earlier. For comparison, Curl-crested Jay Cyanocorax cristatellus, a bird known to have colonised eastern Brazil (Lopes 2008), reached the 
Viçosa region only in the last 15 years (G. T. Mattos pers. comm.). These data suggest that this species inhabited the region prior to forest suppression, maybe restricted to the high altitude grasslands of the nearby Serra do Brigadeiro (see Simon et al. 1999).

Black-masked Finch Coryphaspiza melanotis - Vulnerable (Machado et al. 2005, BirdLife International 2008).

This species was observed three times and photographed at Campo das Vertentes in dry grasslands (farm belonging to Mr. G. C. Fonseca) and at the borders of a seasonally flooded campo limpo (Souza). This species was also observed and photographed at Batateiro on the following dates: II December 2005 (an adult with an immature), 14 July 2006 (three adults), 14 October 2006 (two adults), 26 November 2006 (an adult), and 17 December 2006 (three adults). About 40-50 individuals were observed at Fazenda Monte Carmelo (Ribeirão Piçarrão, Ribeirão Furnas and Ribeirão Buriti Alto) between October 2007-April 2008, inhabiting campo limpo and campo sujo com murundus, both seasonally flooded. Although this species has recently become very local and rare (BirdLife International 2008) our new records, along with recently published others, give a more optimistic prospect for C. melanotis. We found recent records of this species for 14 conservation units in Brazil, four in Argentina, two in Bolivia and one in Paraguay (see Appendix). This species seems to be extinct in Chapada dos Guimarães, Mato Grosso (Lopes et al. 2009).

Tawny-bellied Seedeater Sporophila hypoxantha Data Deficient (Machado et al. 2005).

Marsh Seedeater S. palustris Endangered (Machado et al. 2005, BirdLife International 2008).

Chestnut Seedeater S. cinnamomea Endangered (Machado et al. 2005), Vulnerable (BirdLife International 2008).

Black-bellied Seedeater S. melanogaster Vulnerable (Machado et al. 2005), Near Threatened (BirdLife International 2008).

These four species of Sporophila were observed and photographed on the headwaters of Ribeirão Mandaguari in a seasonally flooded campo sujo on 5 and 11 October 2007. They were foraging in native grasses, associated with a mixed species flock including Plumbeous Seedeater S. plumbea, Yellow-bellied Seedeater S. nigricollis, Double-collared Seedeater S. caerulescens, and Capped Seedeater S. bouvreuil (both $S$. b. bouvreuil and $S$. b. pileata in the same flock). When we returned to this site on 3 November 2007, only S. melanogaster was observed. A fully developed male of $S$. melanogaster was collected at Rio Jacaré, Morro do Ferro, Minas Gerais $\left(20^{\circ} 36^{\prime} \mathrm{S}\right.$ and $44^{\circ} 34^{\prime} \mathrm{W}$; MHNT 4127$)$ on 28 December 1997 . This specimen and five other males were associated in a mixed species flock with S. bouvreuil, S. caerulescens and S. hypoxantha. There are few previous records of these species for Minas Gerais (see Supplementary materials), and its migratory routes are not properly know yet (Silveira 1998, Silva 1999).

\section{Biogeography}

The records of four grassland species at Campo das Vertentes represent a remarkable range extension for these species. Although Campo das Vertentes is depicted in vegetation maps as completely isolated from the Central Brazilian Cerrado (see Figure 1), there seems to be a discrete connection between these grasslands. The highest areas of the southern Espinhaço Range and Serra da Mantiqueira in southeastern Minas Gerais are linked by natural grasslands along the mountain ridges. These grasslands connect the Cerrado to Campos das Vertentes through the municipalities of Congonhas, Lagoa Dourada, Entre Rios de Minas, Tiradentes, São João del Rey, Itumirim, São Vicente de Minas and Minduri (Azevedo 1962).

\section{Conservation}

The southern Espinhaço Range, also know as Quadrilátero Ferrifero, was recognized as being of 'special biological importance' (the highest degree of biological importance) during the recent 
workshop 'Priorities for Biodiversity Conservation in the State of Minas Gerais, Brazil' (Drummond et al. 2005). The main threats to this area are the urban expansion, iron mining, fire, and deforestation (Drummond et al. 2005). At Campo das Vertentes, annual fire and Eucalyptus plantations are the main threats. In the Triângulo Mineiro (the triangular shaped area on the westernmost part of the state, which includes the farms Cocal, Água Emendada and Monte Carmelo), the main threats are clay mining and the replacement of native grasslands with grain crops and sugarcane. All these threats are discussed in detail below.

Fire. Several grassland species are highly sensitive to regular fires (Cavalcanti 1988, Tubelis and Cavalcanti 2000). For example, some bird species usually found in well conserved grasslands in the southern Espinhaço Range, such as Hyacinth Visorbearer Augastes scutatus and C. platensis, are no longer found at Serra do Curral, a mountain in Belo Horizonte, suggesting local extinction (Vasconcelos 1999, 2007). In the Triângulo Mineiro, the expansion of sugarcane plantation causes concern, because farmers set their crops on fire to make harvesting easier, increasing the possibility of fires in the grasslands.

Habitat loss. Natural grasslands frequently give way to pastures of exotic grasses, generally unsuitable for several threatened grassland specialists (Parker and Willis 1997, Costa and Costa 2002). Silviculture is also an important, and generally unnoticed, cause of habitat loss. Eucalyptus and Pinus plantations are one of the few viable economic activities in the poor, shallow, and water deficient soils where grasslands generally occur (Rizzini 1997). The grassland patches sampled at Fazenda Monte Carmelo are small and partially isolated amidst Pinus plantations. Eucalyptus plantations are now expanding at Campo das Vertentes, where we observed the suppression of thousands of hectares of native grasslands. Silviculture is not seen by Brazilian society as a threat to ecosystem integrity, but rather, it is commonly seen as beneficial to wildlife. In a country with prodigious tropical forests, they are popularly thought to be the natural condition of a healthy environment. Grasslands are, conversely, considered as a poorly diversified habitat, and many times confounded with artificial pastures. Therefore, forestry practices are generally referred to as 'reforestation', when actually it is simply the suppression of large tracts of species-rich grasslands by extensive, little-diversified monocultures (Marsden et al. 2001, Willis 2004). Its conservation value is probably no better than that of an avocado or orange plantation.

A new growing threat is the expansion of 'biofuel' enterprises in the Triângulo Mineiro, which is backed by a strong lobby from the state government, facilitating the process of environmental licensing to install alcohol fuel plants. Biofuels are announced by the Brazilian Government to international organizations as 'clean energy', but what we can see is the destruction of Cerrado to plant sugarcane.

Iron mining is the main cause of the suppression of large tracts of a unique habitat, the canga, in the Quadrilátero Ferrifero. This area contains a unique global flora, with several endemic species (Jacobi et al. 2007, Viana and Lombardi 2007). In the region of Uberaba, the mining of refractory clay in seasonally flooded campos, especially in the headwaters of the rivers Uberabinha and Claro, results in the complete suppression or severe modification of natural grasslands.

Another important cause of habitat loss in the high altitude grasslands at the Quadrilatero Ferrifero is urban expansion. With growing urban criminality and the increasing appeal of living close to nature, many people are moving to luxury condominiums in the suburbs of Belo Horizonte. These condominiums are generally said to be 'ecologically correct', but they are not. There is simply no way to replace natural grasslands and forests by houses without severe disturbance.

Roadkills. Although the several dirt roads in the Retiro das Pedras and Serra do Rola Moça State Park are closed to the public, both areas are subject to intensive and illegal off-road vehicle traffic. During one hour on a sunny weekend, we observed three 4 -WD vehicles and 10 motorcycles at Retiro das Pedras, all of them moving at high speed. A paved road also crosses the Serra do Rola Moça State Park. Roads may be a significant source of threat for grassland birds, as verified by França \& Braz (2008), who found road-killed C. caudacuta and C. melanotis at Veadeiros National Park, central Brazil. 


\section{Recommendations}

- Search for grassland specialists not yet recorded in the Espinhaço Range and Campo das Vertentes, such as Dwarf Tinamou Taoniscus nanus, Lesser Nothura Nothura minor, Rufous-sided Pigmy-tyrant, and Ochre-breasted Pipit Anthus nattereri. In the seasonally flooded campos of the Triângulo Mineiro, searches must target the headwaters of the rivers Uberabinha, Claro and Tijuco.

- Create a large conservation unit at Campo das Vertentes devoted to the conservation of grassland habitats. The Ibitipoca State Park, located in the easternmost limits of Campo das Vertentes, is dominated by semi-deciduous forests, not harbouring extensive grassland areas. As a consequence, no species listed in this paper has been recorded in the area so far (Andrade 1996, Pacheco et al. 2008).

- Comply with environmental legislation that ensures the protection of Areas for Permanent Preservation (APPs). These areas, such as river headwaters and riparian forests, are protected by law, and cannot be used for high impact activities such as plantations, cattle raising and mining. Good examples are the seasonally flooded campos at the headwaters of the rivers Claro, Uberabinha and Ribeirão Mandaguari that although theoretically protected, are suffering severe anthropogenic impacts.

- Cease immediately mining of refractory clay at the headwaters of Rio Uberabinha and Rio Claro, where representative tracts of covoais still persist.

- Restrict sugarcane, Eucalyptus and Pinus plantations to previously cleared land, avoiding opening pristine Cerrado and campos.

- Creation of a seal of environmental certification for biofuel activities, especially for the sugarcane sector.

- Expand the Serra do Rola Moça State Park, incorporating large tracts of well conserved grasslands around Retiro das Pedras.

\section{Acknowledgements}

We thank IEF-MG, Satipel Florestal (J. Medeiros and A. G. Ribeiro), and CEMIG for the authorization to conduct this study in areas under their care. Our studies were supported by the CNPq, CAPES, FAPEMIG, Brehm Foundation, American Museum of Natural History, SETE Soluções e Tecnologia Ambiental, Neotropical Bird Club, Conservação Internacional, Pequi, and Fundação O Boticário (Processo 200710116). We thank IBAMA for the collecting permits (No. 10013-1). L. Sueiro, K. Torga, R. M. Valadão, E. Luciano Júnior, J. B. Vasques, R. Lopes, R. Pinheiro, V. Piacentini, F. Schunck, É. Machado, T. Dornas, E. Reis, C. Nogueira, and P. Valdujo helped us with the fieldwork. D. Pioli helped with fieldwork and the English revision of the manuscript. The following curators kindly permitted us access to their collections: M. Rodrigues (DZUFMG), M. Resende (Reserva Ecológica do IBGE), M. Â. Marini (Universidade de Brasília), J. Hidasi (Fundação Museu de Ornitologia and Museu de Zoologia José Hidasi), J. B. Pinho (Universidade Federal de Mato Grosso), H. Fernandes (Museu de Biologia Professor Mello Leitão), H. Alvarenga (Museu de História Natural de Taubaté), J. Cracraft, P. Hart and P. Sweet (American Museum of Natural History), S. Olson and B. Schmidt (National Museum of Natural History), B. Livezey and S. Rogers (Carnegie Museum of Natural History). We also thank the curators of the North American Museums which allowed us to access their on-line database at ORNISNET portal (http://ornisnet.org). LFS is an Associate Researcher of the World Pheasant Association. LEL and MFV benefited from a Collection Study Grant from the American Museum of Natural History.

\section{References}

Andrade, M. A. (1996) As aves na região do Parque Estadual do Ibitipoca: conservação e distribuição. Pp. 61-72 in G. C. Rocha, ed.
Parque Estadual do Ibitipoca - Anais do Seminário de Pesquisa. Juiz de Fora, Brazil: Universidade Federal de Juiz de Fora. 
Azevedo, L. G. (1962) Tipos de vegetação do sul de Minas e campos da Mantiqueira (Brasil). An. Acad. Bras. Cien. 34: 225-234.

Bencke, G. A., Maurício, G. N., Develey, P. F. and Goerck, J. M. (2006) Áreas importantes para a conservação das aves no Brasil, parte I, estados do domínio da Mata Atlântica. São Paulo, Brazil: SAVE Brasil.

BirdLife International (2008) BirdLife's online World Bird Database. http://www. birdlife.org (accessed on 9 Feb 2009).

Bornschein, M. R., Reinert, B. and Bóçon, R. (1996) A new record of the Sickle-winged Nightjar Eleothreptus anomalus for southern Brazil. Bull. Brit. Ornith. Club 116: 125-126.

Brandt, L. F. S. (1998) Geobates poecilopterus (Wied, 1830). Pp. 304-305 in A. B. M. Machado, G. A. B. Fonseca, R. B. Machado, L. M. S. Aguiar and L. V. Lins, eds. Livro vermelho das espécies ameaçadas de extinção da fauna de Minas Gerais. Belo Horizonte, Brazil: Fundação Biodiversitas.

Braz, V. S., Abreu, T. L. S., Lopes, L. E., Leite, L. O., França, F. G. R., Vasconcellos, M. M. and Balbino, S. F. (2003) Brazilian Merganser Mergus octosetaceus discovered in Jalapão State Park, Tocantins, Brazil. Cotinga 20: 68-71.

Cavalcanti, R. B. (1988) Conservation of birds in the Cerrado of central Brazil. Pp. 59-66 in: P. D. Goriup, ed. Ecology and conservation of grassland birds. Cambridge, UK: International Council for Bird Preservation.

Cavalcanti, R. B. (1999) Bird species richness and conservation in the Cerrado region of central Brazil. Stud. Avian Biol. 19: 244-249.

Cleere, N. (2002) A review of the taxonomy and systematics of the Sickle-winged and White-winged Nightjars (Caprimulgidae). Bull. Brit. Ornith. Club 122: 168-179.

Collar, N. J., Gonzaga, L. P., Krabbe, N., Madroño Nieto, A., Naranjo, L. G., Parker, T. A., III and Wege, D. C. (1992) Threatened birds of the Americas: the ICBP/IUCN Red Data Book. Cambridge, UK: International Council for Bird Preservation.

Costa, R. G. A. and Costa, R. V. (2002) Impactos antropogênicos na cobertura florística do pampa gaúcho e seus efeitos sobre a avifauna silvestre. Atual. Ornitol. 109, I1O: 11, 12.

D'Angelo Neto, S. and Queiroz, S. R. (2001) Ocorrência da maria-corruíra (Euscarthmus rufomarginatus) no norte de Minas Gerais, Brasil. Tangara 1: 90-94.

Di Giacomo, A. S. (ed.) (2005) Áreas importantes para la conservación de las aves en la Argentina, sitios prioritarios para la conservación de la biodiversidad. Buenos Aires, Argentina: Aves Argentinas, Associación Ornitológica del Plata.

Drummond, G. M., Martins, C. S., Machado, Â. B. M., Sebaio, F. A. and Antonini, Y. (eds.) (2005) Biodiversidade em Minas Gerais: um atlas para sua conservação. Belo Horizonte, Brazil: Fundação Biodiversitas.

França, F. G. R. and Braz, V. S. (2008) Efeito de rodovias sobre as aves do Parque Nacional Chapada dos Veadeiros. P. 142 in: T. Dornas and M. O. Barbosa, eds. XVI Congresso Brasileiro de Ornitologia - Resumos. Palmas, Brazil: Universidade Federal do Tocantins, Sociedade Brasileira de Ornitologia.

Giulietti, A. M. and Pirani, J. R. (1988) Patterns of geographic distribution of some plant species from the Espinhaço Range, Minas Gerais and Bahia, Brazil. Pp. 39-69 in P. E. Vanzolini and W. R. Heyer, eds. Proceedings of a workshop on Neotropical distribution patterns. Rio de Janeiro, Brazil: Academia Brasileira de Ciências.

Jacobi, C. M., Carmo, F. F., Vincent, R. C. and Stehmann, J. R. (2007) Plant communities on ironstone outcrops: a diverse and endangered Brazilian ecosystem. Biodivers. Conserv. 16: 2185-2200.

Kirwan, G. M., Martuscelli, P., Silveira, L. F. and Williams, R. S. R. (1999) Recent records of the Sickle-winged Nightjar Eleothreptus anomalus in south-east Brazil. Bull. Brit. Ornith. Club 119: 202-206.

Krabbe, N. (2007) Birds collected by P. W. Lund and J. T. Reinhardt in south-eastern Brazil between 1825 and 1855 , with notes on P. W. Lund's travels in Rio de Janeiro. Rev. Bras. Ornitol. 15: 331-357.

Lopes, L. E. (2008) The range of the Curlcrested Jay: lessons for evaluating bird endemism in the South American Cerrado. Divers. Distrib. 14: 561-568. 
Lopes, L. E., Pinho, J. B., Bernardon, B., Oliveira, F. F., Bernardon, G., Ferreira, L. P., Vasconcelos, M. F., Maldonado-Coelho, M., Nóbrega, P. F. A. and Rubio, T. C. (2009) Aves da Chapada dos Guimarães, Mato Grosso, Brasil: uma síntese histórica do conhecimento. Pap. Avulsos Zool. 49: 9-47.

Machado, A. B. M., Martins, C. S. and Drummond, G. M. (2005) Lista da fauna brasileira ameaçada de extinção, incluindo as listas das espécies quase ameaçadas e deficientes em dados. Belo Horizonte, Brazil: Fundação Biodiversitas.

Marsden, S. J., Whiffin, M. and Galetti, M. (2001) Bird diversity and abundance in forest fragments and Eucalyptus plantations around an Atlantic forest reserve, Brazil. Biodivers. Conserv. 10: 737-751.

Melo Júnior, T. A. (1998) Poospiza cinerea Bonaparte, 1850. Pp. $387-388$ in A. B. M. Machado, G. A. B. Fonseca, R. B. Machado, L. M. S. Aguiar and L. V. Lins, eds. Livro vermelho das espécies ameaçadas de extinção da fauna de Minas Gerais. Belo Horizonte, Brazil: Fundação Biodiversitas.

Olson, D. M., Dinerstein, E., Wikramanayake, E. D., Burgess, N. D., Powell, G. V. N., Underwood, E. C., D'Amico, J. A., Itoua, I., Strand, H. E., Morrison, J. C., Loucks, C. J., Allnutt, T. F., Ricketts, T. H., Kura, Y., Lamoreux, J. F., Wettengel, W. W. P. H. and Kassem, K. R. (2001) Terrestrial ecoregions of the world: a new map of life on Earth. BioScience 51: 933-938.

Oren, D. C. (1991) Aves do estado do Maranhão, Brasil. Goeldiana Zool. 9: 1-55.

Pacheco, J. F., Parrini, R., Lopes, L. E. and Vasconcelos, M. F. (2008) A avifauna do Parque Estadual do Ibitipoca e áreas adjacentes, Minas Gerais, Brasil, com uma revisão crítica dos registros prévios e comentários sobre biogeografia e conservação. Cotinga 30: 16-32.

Parker, T. A., III and Willis, E. O. (1997) Notes on three tiny grassland flycatchers, with comments on the disappearance of South American fire-diversified savannas. Ornith. Monogr. 48: 549-555.

Paynter, R. A., Jr. and Traylor, M. A., Jr. (1991) Ornithological gazetteer of Brazil, 2 vols. Cambridge, USA: Museum of Comparative Zoology.
Pelzeln, A., von (1868-1870) Zur ornithologie Braziliens: resultate von Johann Natterers reisen in den Jahren 1817 bis 1835 , parts I-IV. Vienna, Austria: Pichler's Withwe \& Sohn.

Reinhardt, J. (1870) Bidrag til Kundskab om Fuglefaunaen i Brasiliens Campos. Vidensk. Meddel. Naturhist. Foren. Kjöbenhavn 1/7: 21/28: 1-124, 315-457.

Ribeiro, J. F. and Walter, B. M. T. (1998) Fitofisionomias do bioma Cerrado. Pp. 89-166 in: S. M. Sano and S. P. Almeida, eds. Cerrado: ambiente e flora. Planaltina, Brazil: Embrapa.

Ribon, R. (2002) Colonization of eastern Brazil by the Cinereous Warbling-finch, with some comments on its natural history. P. 585 Third North American Ornithological Conference - Abstracts. New Orleans, USA: American Ornithologists' Union.

Ridgely, R. S. and Tudor, G. (1994) The birds of South America, vol. 2, the suboscine passerines. Austin, U.S.A.: University of Texas Press.

Rizzini, C. T. (1997) Tratado de fitogeografia do Brasil. Rio de Janeiro, Brazil: Âmbito Cultural Edições Limitadas.

Sick, H. (1997) Ornitologia Brasileira. Rio de Janeiro, Brazil: Nova Fronteira.

Silva e Silva, R. (2005) Biologia reprodutiva de Geositta poeciloptera (Passeriformes: Furnariidae) em Minas Gerais. P. 28 in: A. Aleixo, ed. XIII Congresso Brasileiro de Ornitologia - Resumos. Belém, Brazil: Museu Paraense Emílio Goeldi, Universidade Federal do Pará.

Silva, J. M. C. (1999) Seasonal movements and conservation of seedeaters of the genus Sporophila in South America. Stud. Avian Biol. 19: 272-280.

Silveira, L. F. (1998) The birds of Serra da Canastra National Park and adjacent areas, Minas Gerais, Brazil. Cotinga 10: 55-63.

Simon, J. E., Ribon, R., Mattos, G. T. and Abreu, C. R. M. (1999) A avifauna do Parque Estadual da Serra do Brigadeiro, MG. Rev. Árvore 23: 33-48.

Stotz, D. F., Fitzpatrick, J. W., Parker, T. A., III and Moskovits, D. K. (1996) Neotropical birds: ecology and conservation. Chicago, U.S.A. University of Chicago Press.

Straube, F. C. (1990) Notas sobre a distribuição de Eleothreptus anomalus (Gould, 1837) e 
Caprimulgus longirostris longirostris Bonaparte, 1825 no Brasil (Aves: Caprimulgidae). Acta Biol. Leopoldensia 12: 301-312.

Traylor, M. A., Jr. and Fitzpatrick, J. (1982) A survey of Tyrant Flycatchers. Living Bird 19: 7-50.

Tubelis, D. P. and Cavalcanti, R. B. (2000) A comparison of bird communities in natural and disturbed non-wetland open habitats in the Cerrado's central region, Brazil. Bird Conserv. Internatn. 10: 331-350.

Vasconcelos, M. F. (1999) Natural history notes and conservation of two species endemic to the Espinhaço Range, Brazil: Hyacinth Visorbearer Augastes scutatus and Grey-backed Tachuri Polystictus superciliaris. Cotinga 11: 75-78.

Vasconcelos, M. F. (2007) Aves observadas no Parque Paredão da Serra do Curral, Belo Horizonte, Minas Gerais, Brasil. Atual. Ornitol. 136: 6-11.

Vasconcelos, M. F. and D'Angelo Neto, S. (2007) Padrões de distribuição e conservação da avifauna na região central da Cadeia do Espinhaço e áreas adjacentes, Minas Gerais, Brasil. Cotinga 28: 27-44.
Vasconcelos, M. F., D'Angelo Neto, S., Kirwan, G. M., Bornschein, M. R., Diniz, M. G. and Silva, J. F. (2006) Important ornithological records from Minas Gerais state, Brazil. Bull. Brit. Ornith. Club. 126: 212-238.

Viana, P. L. and Lombardi, J. A. (2007) Florística e caracterização dos campos rupestres sobre canga na Serra da Calçada, Minas Gerais, Brasil. Rodriguésia 58: 159-177.

Vickery, P. D., Tubaro, P. L., Silva, J. M. C., Peterjohn, B. G., Herkert, J. R. and Cavalcanti, R. B. (1999) Conservation of grassland birds in the western hemisphere. Stud. Avian Biol. 19: 2-26.

Vincent, R. C., Jacobi, C. M. and Antonini, Y. (2002) Diversidade na adversidade. Ciênc. Hoje 31: 64-67.

Wege, D. C. and Long, A. J. (1995) Key areas for threatened birds in the Neotropics. Cambridge, UK: BirdLife International.

Willis, E. O. (2004) Birds of a habitat spectrum in the Itirapina savanna, São Paulo, Brazil (1982-2003). Braz. J. Biol. 64: 901-910.

Willis, E. O. and Oniki, Y. (1992) Losses of São Paulo birds are worse in the interior than in the Atlantic Forest. Ciênc. Cult. 44: 326-328.

\section{LEONARDO ESTEVES LOPES*, MARCELO FERREIRA DE VASCONCELOS, DIEGO HOFFMANN \\ Departamento de Zoologia, ICB, Universidade Federal de Minas Gerais, Caixa Postal 486, Belo Horizonte, Minas Gerais, 31270-910, Brazil.}

\section{GUSTAVO BERNARDINO MALACCO}

Associação para Gestão Socioambiental do Triângulo Mineiro, Al. Serra Dourada 209, Uberlândia, Minas Gerais, 38412-154, Brazil.

\section{EDUARDO FRANÇA ALTEFF}

Pós-graduação em Ecologia e Conservação de Recursos Naturais, IB, Universidade Federal de Uberlândia, Caixa Postal 593, Uberlândia, Minas Gerais, 38400-902, Brazil.

\section{LUÍS FÁBIO SILVEIRA}

Departamento de Zoologia, Museu de Zoologia da Universidade de São Paulo, Caixa Postal 42494, São Paulo, São Paulo, 04218-97o, Brazil.

${ }^{*}$ Author for correspondence; e-mail: leo.cerrado@gmail.com 